DOI : 10.18572/1813-1247-2019-1-6-10

НЕКОТОРЫЕ ИТОГИ НОВОГО ЭТАПА

АДМИНИСТРАТИВНОЙ РЕФОРМЫ: ВЫВОДЫ И ВОПРОСЫ

\author{
Осинцев Дмитрий Владимирович, \\ профессор кафедры теории и практики управления \\ Уральского государственного юридического университета, \\ доктор юридических наук, доцент \\ dimios@mail.ru \\ Домченко Артем Сергеевич, \\ аспирант кафедры теории государства и права, \\ конституционного и административного права \\ Южно-Уральского государственного университета \\ artem.domchenko@yandex.ru
}

В статье анализируется Постановление Правительства Российской Федерации от 13 июня 2018 г. № 676 «0 внесении изменений в некоторые акты Правительства Российской Федерации в связи с оптимизацией порядка разработки и утверждения административных регламентов», освещаются некоторые новеллы административно-правовой регламентации, построения принципиально новой правовой основы предмета административно-правового регулирования, изменения структуры источников административного права. Предлагается авторское, критически переосмысленное видение результатов нового этапа административной реформы.

Ключевые слова: административная реформа, государственная функция, методы административноправового воздействия, административный регламент, стандарт публичного управления.

\title{
SOME RESULTS OF THE NEW ADMINISTRATIVE REFORM STAGE: CONCLUSIONS AND QUESTIONS
}

\author{
Osintsev Dmitriy V. \\ Professor of the Department of Theory and Practice \\ of Management of the Ural State Law University \\ Doctor of Law \\ Associate Professor \\ Domchenko Artem S. \\ Postgraduate Student of the Department of Theory of State and Law, \\ Constitutional and Administrative Law of the South Ural State University
}

The article analyzes the Decree of the Government of the Russian Federation dated 13.06.2018 № 676 "On amendments to some acts of the Government of the Russian Federation in connection with the optimization of the procedure for the development and approval of administrative regulations", highlights some of the novelties of administrative and legal regulation, building a fundamentally new legal basis of the subject of administrative and legal regulation, changing the structure of sources of administrative law. The author's, critically reconsidered, vision of results of a new stage of administrative reform is offered.

Keywords: administrative reform, state function, methods of administrative and legal influence, administrative regulations, standard of public administration. 